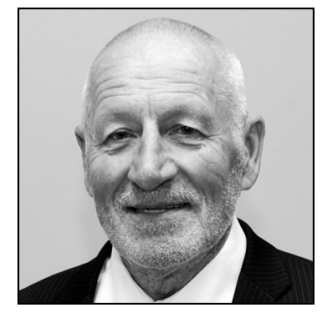

$\underline{\text { Janis Rozenfelds }}$

Professor

University of Latvia

\title{
Reform of Land Registration in Latvia
}

\section{Introduction}

Usually a distinction is drawn between 'land' and 'chattels'. One source describes the difference thus: 'For example, a brick in a builder's yard is a chattel; once used to build a wall, it becomes a part of the land; and if the wall is knocked down, the bricks become chattels again'. ${ }^{*}$

What is known as the superficies solo cedit principle is extracted from the sources of Roman law (Gaius, D. $41,1,7,10)$ :

When someone builds on his own site with another's materials, he is deemed to be owner of the building because all that is built on it becomes part of the soil. However, the owner of the materials does not thereby lose his ownership of them [...]. Hence, if the house should collapse for some reason, the owner of the materials can have a vindication for them and have an action for their production. ${ }^{*}$

The same principle is prescribed by Section 968 of the Latvian Civil Law ${ }^{*}$ (hereinafter also 'CL'): 'A building erected on land and firmly attached to it shall be recognised as a part thereof.'

Similar use of the term 'land plot' (the concept of Grundstück) can be found in §94 of the German Civil $\mathrm{Code}^{*} 4$ (Bürgerliches Gesetzbuch, or BGB).

Although the Latvian CL does not use the term 'land plot' or 'plot of land', it rather frequently employs the term 'immovable property' (see, for instance, Subdivision II of Sub-chapter IV of Chapter III: 'Rights of Owners in Regard to Immovable Property in General'), which is regarded as a synonym for the term 'immovable' in the doctrine associated with the Latvian CL. ${ }^{*}$

Therefore, the terminology of the Latvian CL meshes with the common understanding of what the 'land', 'plot of land', or 'immovable' is, even though Latvian law does not always draw strict distinctions among the above-mentioned terms or mark out a clear delineation between the immovable as an object of rights and the right or interest in the immovable.

E.H. Burn, J. Cartwright. Maudsley \& Burn's Land Law Cases and Materials, Ninth Edition. Oxford University Press 2009, p. 6.

2 The Digest of Justinian, Volume 4: English Language Translation Edited by Alan Watson. University of Pennsylvania Press 1998, p. 3.

3 Civillikums (Civil Law). 'Valdības Vēstnesis', 41, 20.2.1937 (in Latvian).

4 Bürgerliches Gesetzbuch. BGBl. I S. 42, 2909; 2003 I S. 738. English text available at http://www.gesetze-im-internet.de/ englisch_bgb/ (most recently accessed on 6.2.2014).

5 A. Grūtups, E. Kalniņš. Civillikuma komentāri. Trešā daḷa. Lietu tiesības. Īpašums ['Comments on the Civil Law, Part III: Property Law, Ownership'], 2nd edition. TNA 2002, p. 23 (in Latvian). 
In line with other codes of civil-law systems, the CL does not use the term 'estate' in the meaning of the 'amount of a person's interest in land', ${ }^{* 6}$ although the term 'estate' might be used sometimes in the meaning associated with heritage (see Sections 1021 and 1288 of the CL).

Although the CL distinguishes between movable (chattels) and immovable things (in Section 842), very little attention is devoted to this important feature of modern civil law. In this regard, the regulation in the CL is strikingly similar to that of Roman law. For instance, the CL provides for acquisition of ownership pursuant to delivery (in its Sections 987-997) no matter whether it is a chattel or an immovable at issue. Acquisition of property through prescription (addressed in Sections 998-1031 of the CL) refers to chattels just as well as to immovables. The only distinction mentioned here is in Section 1023 ('Prescription for the acquisition of movable property shall be considered completed after the elapsing of one year') as compared to Section 1024 ('A person who has possessed an immovable property for a ten-year period in accordance with the provisions on prescription [...] shall be recognised as a person who has acquired such immovable property through prescription'). Although acquisition of immovable property through prescription usually is regarded as incompatible with the land-registration system (there are a few exceptions, but these have to do only with unregistered rights ${ }^{*}$, not those rights that are already registered-praescriptio contra tabulas), the possibility of such acquisition is still admitted, at least in theory. Moreover, it has even been concluded that in such cases the rights of an unregistered proprietor can lead to rectification in favour of the registered adverse rights of another person. ${ }^{* 8}$ However, such conclusions seem to be based on outdated sources and for this reason can be regarded as incorrect. ${ }^{*}$

As to the principles of land registration, Latvian law indirectly features all of the most important.

The principle of obligatory registration is prescribed by Section 1477 of the Latvian CL: 'Corroboration shall be required in those cases wherein the transaction grants property rights over immovable property.'

The principle of public credibility is prescribed by Section 994 of the CL: 'Only such persons shall be recognised to be owners of immovable property as are registered in the Land Register as such owners.'

The principle of certainty is prescribed by Section 993 (3) of the CL, which states that 'each immovable property that is not an appurtenance to another such property must be registered in the name of the new owner as a new [...] parcel'. This principle is also prescribed by Section 29 of the Land Register Law ${ }^{* 10}$ : 'A separate division for each independent immovable property shall be opened in a land register.'

The principle of seniority is prescribed by Section 35 of the Land Register Law: '[T] he priority right of corroboration shall be determined in accordance with the time of corroboration in a division of a land register.'

These principles are supplemented by the principle of a relevant process in a parallel with the principle of transparency, which is prescribed by Section 101 of the Land Register Law: 'Anyone may examine land registers and request references, excerpts, true copies, and certificates therefrom.'

Also the principle of disposition is prescribed, by Section 57 of the Land Register Law: 'Corroboration may be requested only by owners of immovable property and persons for the benefit of whom or against whom the corroboration is performed, as well as in the [other] cases specified by law-[involving] judicial and other state authorities or officials.'

The principle of legality is prescribed by Section 77 of the Land Register Law, which states the following:

When examining a request for corroboration, a judge of a Land Register office shall only ascertain the following:

1) that the request is in conformity with the provisions of Sections 57,58 , and $60-68$;

2) that other, already corroborated rights or another request for corroboration that arrived on the same day is not an obstacle to corroboration (Section 75);

3) that the rights the corroboration of which is requested are among the rights referred to in Sections 31 and 44 that are related to an immovable property;

4) that the documents upon which a request is grounded do not contain anything that is obviously illegal.

6 B.A. Garner (ed.). Black's Law Dictionary, 7th ed. West Group 1999, p. 567.

7 S. Jourdan. Adverse Possession. LexisNexis 2003, p. v (ISBN 0406982511).

A. Grūtups, E. Kalniņš (see Note 6), p. 158 (in Latvian).

9 J. Rozenfelds. Aktuālas lietu tiesību problēmas ['Topical issues of property law']. Aktuālas tiesību realizācijas problēmas. Collection of papers of the 69th Conference of the University of Latvia. Latvijas Universitātes 69. konferences rakstu krājums. Riga, Latvia: LU Akadēmiskais apgāds editorial panel Prof. J. Rozenfelds, Prof. K. Torgāns, Prof. I. Čepāne, Prof. S. Osipova, Prof. R. Balodis, Prof. V. Liholaja, Associate Prof. A. Kučs) 2011, pp. 9-16 (in Latvian).

10 Zemesgrāmatu likums (Land Register Law). 'Ziṇotājs', 16, 29.4.1993 (in Latvian). 
Finally, the principle of priority is prescribed by Section 73 of the Land Register Law, which states that the '[p]riority right to fulfilment shall, with account taken of the exceptions provided for in the following sections (Sections 74 and 75), be given to such a request for corroboration as was received earlier in a Land Register office', and Section 74: 'Requests for corroboration that are submitted to a Land Register office during the working hours of one and the same day or are received in an office by post by the end of reception hours shall be recognised as having arrived at the same time.'

However, one of the most important principles, the backbone of any land-registration system (numerus clausus law), which limits the number of types of right that could be acknowledged as associated with the character of real property, is nowhere expressly stated-in a contrast against, for instance, the Swiss Civil code $^{* 11}$ with its Section (1) 959).

All of the above-mentioned principles were established as soon as the Latvian CL and the Land Register Law of 1937 were reinstated. However, it turned out that, in practice, some of those principles were neglected. This probably can be explained by lack of understanding of the above-mentioned principles. Only after considerable time had passed did there arise awareness as to how important these principles are for the property market.

The Latvian CL declares unrestricted rights of an owner to the airspace above the immovable property and the land strata. Physical unity of property is understood as restrictions provided by law to horizontal division of the immovable property or to fragmentation of property (the so-called entropy of the physical unity of property) ${ }^{*}{ }^{*}$, ensuring the physical unity of property both in the land strata below and in the airspace above the property, on the ad caelum principle. ${ }^{*} 13$ In a difference from most modern laws of its kind, the CL formally does not allow any deviations from physical unity of property (see Section 1042). Fundamental importance was assigned to the physical unity of property during the process of drafting of the CL. It was highlighted that the CL was following the general tendencies of codification of its time: '[W]ith the last relics of feudal law, the European codes are gradually losing the double property [i.e., a dualistic approach] and building a united system of ownership rights' by abandoning 'civil-law feudalism," 14 .

Latvian CL uses the term 'land strata', while the law titled 'On Subterranean Depths" ${ }^{\text {"* } 15}$ uses, , the term 'subterranean depths'. ${ }^{* 16}$

There are four types of rights to another's property (ius in re aliena) under the Latvian CL-a servitude, the real charge, a pledge right, and a right of pre-emption. The first of these is such a right in respect of the property of another as restricts ownership rights associated with it, with respect to utilisation, for the benefit of a certain person or a certain parcel of land (see Section 1130).

Attached to immovable property, a real charge is a permanent duty to provide the specified performance in terms of money, in kind, or by corvée, repeatedly (see Section 1260). This institution can be regarded as equivalent to what is defined by the Estonian Law of Property Act, in the first part of its Section 229 ('An immovable may be encumbered such that the actual owner of the immovable must pay periodic payments in money or in kind to the person for whose benefit the real encumbrance is established, or perform particular acts').

A pledge right is a right with regard to property of another (addressed in Section 841) on the basis of which the property serves to secure the claim of a creditor such that the creditor is able to receive from the property payment for said claim (see Section 1278).

11 Zivilgesetzbuch (Swiss Civil Code). English text available at http://www.admin.ch/ch/e/rs/2/210.en.pdf (most recently accessed on 6.2.2014).

12 F. Parisi. Entropy of property. Available at http://www.law.gmu.edu/assets/files/publications/working_papers/o1-14.pdf (most recently accessed on 6.2.2014).

13 The ad caelum approach was developed in the Middle Ages from a fragment of Roman law in the Code of Justinian (see http:// www.duhaime.org/LegalDictionary/C/CuiusEstSolumEjusEstUsqueAdCaelum.aspx (most recently accessed on 6.2.2014) - D. 43, 24, 22, 4, a reference to the Roman law made in the prototype of the CL's Article 1042-i.e., Article 877 of the Codification of the Baltic Local Laws (BLL), as quoted from Свод Гражданских Узаконений Губерний Прибалтийских. Издание 1864 года, со включением статей по Продолжению1890 года. - С. Петербург. Издание кодификационного отдела при государственном совете, б.г. (in Russian), by means of the Civil Law. See also Kodifikācijas nodaļas 1937. gada izdevums. Riga, Latvia: Trešais iespiedums 1938 (in Latvian).

14 O. Ozolinšš. Civiltiesību reforma Latvijā ['Reform of civil law in Latvia’]. - Darbam un tiesībām. Latvijas krimināltiesību biedrības izdevums 1939, p. 158 (in Latvian).

15 Likums 'Par zemes dzīlēm' (law ‘On Subterranean Depths'). 'Latvijas Vēstnesis', 87 (572), 21.5.1996 (in Latvian).

16 J. Rozenfelds. Entropy of physical unity of property (ad caelum) in the Latvian law: The quality of legal acts and its importance in contemporary legal space. A paper at the International Scientific Conference, University of Latvia, 4-5 October 2012, p. 615 of proceedings document (ISBN 978-9984-45-564-8). 
Next, a right of pre-emption is a right to acquire immovable property alienated by another person, by taking precedence over the acquirer thereof in relation to priority as against him, and the assumption of his or her rights (see Section 1381).

The practice applied for land registration initially (until the Soviet invasion in 1940) did not fix any buildings in place. 'Inventory' of the buildings was introduced only during the Soviet occupation.

\section{Splitting of the land unit during introduction of the Civil Law (the civil code)}

In the restoration of the Latvian CL of 1937, which was abandoned during the Soviet occupation (formally it ceased existing as law on 26 November 1940) ${ }^{* 17}$ and reinstated on 7 July 1992, there was introduced an important additional feature that was at odds with the important superficies solo cedit principle-which had formed the backbone of the original version of the CL.

The law On [the] Time and Procedures for Coming into Force of [the] Introduction, Inheritance and Property Law Part of the Renewed Civil Law of the Republic of Latvia of $1937^{* 18}$, of 7 July 1992 (in force since 1 September 1992), restored the CL as a complex act and at the same time applied several exceptions to Section 968 of the Latvian CL regarding buildings erected during the Soviet occupation. From this point on, the formerly clear-cut understanding of what is 'land', a 'land plot', or an 'immovable' was blurred.

This status has become known as 'dualistic property' though also sometimes-erroneously-applied in a system of 'divided property'. A system of divided property involves existence of separate rights over land owned by another person. This refers to the right to the property of another (ius in re aliena) that may manifest itself as a servitude, a hereditary leasehold (emphyteusis), or the right to build (superficies), while a united property is maintained. The system of divided property is a restriction to the ownership right in favour of another person's right. A dualistic system of property, in contrast, allows parallel existence of separate ownership rights-to the building and to the land. That is, the dualistic system is based upon the presumption that two sovereign ownership rights linked to one and the same spatially delimited object are possible. ${ }^{*} 19$

The main difference between the system of divided and that of dual-nature property lay in the manner in which the property was registered in the land register. While property associated with the former was registered in the same division (folio) of the Land Register (or Zemesgrāmata), the latter had to be registered in two separate divisions of the register as soon as it appeared, in a completely new phenomenon arising in 1993. This was a grave consequence of literal interpretation of what was prescribed by Section 29 of the Land Register Law (adopted on 22 December 1937, restored on 4 May 1993): 'A separate division for each independent immovable property shall be opened in a land register.'

At first glance, the meaning of this norm seems clear enough. As soon as it is declared that some buildings should be regarded not as a part of land but as an 'exception' to the principle of superficies solo cedit, a new division (again, folio) should be opened for every such property.

Should that norm have been interpreted more flexibly, the fatal mistake could have been avoided. Unfortunately, at the time when this dual-registration system was launched, the law was still being interpreted in a very narrow way, as was customary for lawyers of the old Soviet school. ${ }^{*}{ }^{2}$

Thus two separate immovable properties were 'created' with the opening of two separate divisions in the Land Register, while in the common understanding there is simply a chattel (made of construction materials) built on the land, with these two physically 'separate' items being, in fact, the same land unit.

17 Latvijas PSR Tautas Komisāru Padomes paziņojums 1940.g. 25. novembrī. KPFSR Civilkodeks ['announcement of the Council of National Commissioners of the Latvian Soviet Socialist Republic dated 25 November 1940, on the civil code of the Russian Soviet Federative Socialist Republic']. Riga, Latvia: Latvijas PSR Tieslietu Tautas komisariāta izdevums 1940 (in Latvian).

18 Likums 'Par atjaunotā Latvijas Republikas 1937. gada Civillikuma ievada, mantojuma tiesību un lietu tiesību daḷas spēkā stāšanās laiku un kārtību' (law 'On [the] Time and Procedures for Coming into Force of [the] Introduction, Inheritance and Property Law Part of the Renewed Civil Law of the Republic of Latvia of 1937'). 'Ziṇotājs', 29, 30.7.1992 (in Latvian).

19 J. Rozenfelds. Superficies solo cedit in Latvian law. - Journal of the University of Latvia: Law 2013/5, pp. $120-136$.

20 J. Rozenfelds. Latvijas privāttiesību attīstības tendences pēc neatkarības atjaunošanas de facto ['Trends in the development of private law since the de facto renewal of Latvian independence']. Tiesību harmonizācija Baltijas jūras reǵionā pēc ES paplašināšanās. Collection of papers of the international conference in 2007. LU Akadēmiskais apgāds 2012, pp. 381-389 (ISBN 978-9984-45-531-0). 


\section{Implementation of the law in practice}

Nobody could imagine how widespread and far-reaching those changes would become in practice. Once established, the separate rights to buildings became more and more complicated in the course of time.

Although it is not possible to establish a direct connection between the dramatic growth in split or divided property and the new ways of interpreting the law related to the land-registration technique, still it should not be viewed as a pure coincidence that at the time when numerous new split properties had to be registered in the Land Register, some authors offered the idea that the strict margins of the regulation of property rights to be registered in the Land Register could be widened by means of analogy.

For instance, by applying disposition as described in Section 2126 of the Latvian CL ('Upon registering a lease or rental contract in the Land Register, the lessee or a tenant shall acquire property rights, which are valid also with respect to third persons'), it would be possible to register in the Land Register an agreement reached between or among co-owners of a given building and thereby solve a problem that otherwise could lead to inevitable division of the property, the latter seeming impractical. ${ }^{* 21}$

This idea was opposed, however, by another author, who claimed that using of analogy in such cases should be regarded as violation of the numerous clausus principle. ${ }^{* 22}$ The practice with the former theory prevailing was shaken by the fierce criticism of the established pattern. However, after a short time during which applications to register such agreements were rejected, the previous practice was reinstated, thanks to a crucial ruling of the Supreme Court stating that such agreements can indeed be registered, given that personal rights are also 'connected' with the rights in rem. ${ }^{*} 23$ Perhaps the very fact that numerous agreements of such a kind had already been registered in the Land Register facilitated this turn of the tide.

So, if until the above-mentioned ruling, it was possible-at least in theory-to insist that the numerous clausus principle, although not expressly set forth in Latvian law, nevertheless plays some role as a tool for distinction of rights in rem from rights in personam, any such reflection faded in light of the 'fit for all' formulation by the Supreme Court: since almost anything is 'connected' to something else, that court ruling disrupted the line between the two types of rights that had existed, although not always clearly, thus far.

\section{4. 'Mandatory rental payment', amendment in 1997, and 'long lease' agreements and construction on another's land}

Soon after the situation of dual property was created, it became apparent that somehow the relationship between the owner of the building on another's land and the owner of the encumbered land must be resolved. This necessity arose from the very fact that by encumbering the land with someone else's property rights to a building on the same land, the land owner is entitled to compensation by the building's owner. Somehow, the practitioners who were first faced with this problem came up with the idea that such compensation could be defined as 'rental payment'. Since the legislation of the time did not deal with this problem, somebody expressed the idea that there was indeed some similarity to a rental contract ${ }^{*} 24$ by analogy with what could be found in Section 2123 of the Latvian CL ('If lease or rental payment has not been specifically agreed upon but the same subject matter had previously been leased or rented by the same person, then it shall be presumed that the previous provisions have not been changed. However, if such a standard does not exist and the parties have expressed only general statements that the payment shall be agreed upon between them, the amount of the payment shall be determined by a court at its discretion').

21 A. Grūtups, E. Kalniņš. Civillikuma komentāri. Trešā daḷa. Lietu tiesības. Īpašums ['Comments to the Civil Law, Part III: Property law, ownership']. Otrais papildinātais izdevums / TNA 2002, p. 263 (in Latvian).

22 E. Virko. Zemesgrāmatu pieejamība un ticamība (Availability and Credibility of Land Registers). 'Jurista Vārds', 1.4.2008 13 (517) (in Latvian).

23 Latvijas Republikas Augstākās tiesas Senāta Civillietu departamenta 5.12.2012. spriedums lietā Nr. SKC-18oo (Judgement SKC 1800, adopted by the Civil Case Department of the Senate for the Supreme Court of the Republic of Latvia on 5.12.2012). Available at http://at.gov.lv/files/uploads/files/archive/department1/2012/1800-skc-2012.doc (most recently accessed on 10.2.2014) (in Latvian).

24 A. Grūtups, E. Krastiņš. İpašuma reforma Latvijā ['Reform of Ownership in Latvia']. Riga, Latvia: Mans İpašums 1995, p. 309 (in Latvian). 
Notwithstanding the fact that an 'analogy' between the situation described in Section 2123 of the CL and the artificially created split of the encumbered plot of land into two separate immovable properties hardly existed, the idea of the 'mandatory rental payment' soon became a common pattern in the proceedings that were usually initiated by the owners of the encumbered plot of land.

Later on, in consequence of the amendments to the law on restoration of property rights and privatisation, these 'mandatory rental payment' became the norm.

The first subsection of Section 12 of the Latvian Cities Land Reform Act ${ }^{* 25}$ of 20 November 1991 originally was worded thus:

In all [...] cases wherein the original owner's land has [in the meantime] been built upon, or where, in accordance with urban planning and construction projects, it is intended to erect thereon constructions necessary to satisfy the needs of society, the former owners of the land or their heirs shall be entitled, as they choose:

- to claim restitution of their title to the property and to obtain from the owner of the building or construction [...] the payment of rent, of which the maximum amount shall be fixed by the Cabinet [...]; or

- to request that they be granted the right of ownership or use of another plot of land, of the same value, situated within the administrative boundaries of the same town, depending on the intended use of such land; or

- to receive compensation in accordance with the statutory conditions.

The law of 8 May $1997^{* 26}$, which entered into force on 6 June of the same year, added to that subsection the following language: 'Where the former owners of the land or their heirs have recovered title to land on which are erected any facilities [...], the annual amount of rent payable for the land shall not exceed five per cent of its cadastral value.'

\section{The 'voluntarily divided plot of land'}

Amendments to the law On [the] Time and Procedures for Coming into Force of Introduction, Inheritance and Property Law Part of the Renewed Civil Law of the Republic of Latvia of $1937^{* 27}$ (introduced on 24 April 1997 and in effect since 21 May 1997) applied the above-mentioned exception to the principle of superficies solo cedit not only to the dwellings erected during the Soviet period but also to those buildings that had been erected after introduction of the Latvian CL if the land was granted on the basis of a lease agreement for at least 10 years and if the lessor gave his or her permission for the construction work. This specific case became nicknamed the 'voluntarily divided property' for purposes of distinguishing it from the properties covered by the earlier regulation, which dealt with the dwellings erected during the Soviet occupation. The latter from now on would be known as dealing with 'compulsorily divided property'. This option was exploited by numerous developers of newly created residential blocks, which were then divided into individual flats and eventually sold to private persons. Business went smoothly until the crisis of 2008 struck. As a part of the notorious austerity measures, the Cabinet introduced a special tax on buildings used as a dwelling (on top of the tax on the immovable property-i.e., on the land-that already existed). At the same time, apparently for fiscal reasons, the cadastral value of the property increased dramatically. From this time on, the rent payments collected by land-owners from the owners of the buildings on the 'divided properties' have been a hot topic.

'Mandatory rent payment' became subject to numerous changes with the law On the Land Reform in the Cities of the Republic of Latvia. It was revised repeatedly: via amendments on 6 December $2007^{* 28}$; after

25 Likums 'Par zemes reformu Latvijas Republikas pilsētās' (Latvian Cities Land Reform Act). 'Ziṇotājs', 49, 19.12.1991 (in Latvian).

26 Grozijumi likumā 'Par zemes reformu Latvijas Republikas pilsētās' (Amendments to the Law 'On the Land Reform in the Cities of the Republic of Latvia'). 'Latvijas Vēstnesis', 126/127 (841/842), 23.5.1997 (in Latvian).

27 Grozijums likumā 'Par atjaunotā Latvijas Republikas 1937.gada Civillikuma ievada, mantojuma tiesību un lietu tiesību dạ̦as spēkā stāšanās laiku un kārtību' (Amendments to the Law 'On [the] Time and Procedures for Coming into Force of [the] Introduction, Inheritance and Property Law Part of the Renewed Civil Law of the Republic of Latvia of 1937'). 'Latvijas Vēstnesis', 112 (827), 7.5.1997 (in Latvian).

28 Grozijums likumā 'Par zemes reformu Latvijas Republikas pilsētās' (Amendments to the Law 'On the Land Reform in the Cities of the Republic of Latvia'). 'Latvijas Vēstnesis', 199 (3775), 12.12.2007 (in Latvian). 
having been scrutinised by the Constitutional Court, which issued a decision on 15 April $2009^{* 29}$ (admitting that the previous amendment violated property rights protected by Section 105 of the Constitution and therefore was invalid with effect from 1 November 2009), with the new version raising the percentage of mandatory rent to six per cent of the cadastral value of the plot of land; and once more, after a second decision of the Constitutional Court, handed down on 27 January $2011^{*} 30$.

\section{The problem of restoration of physical unity of plots of land}

With the passing of time, the ephemeral character of the 'coexistence' of two rights-the ownership of land and the ownership of the building on the relevant plot of land-became more and more apparent.

Dissatisfaction was felt by both parties. The holders of the encumbered plots of land were unhappy because they felt that their rights were limited in comparison with the situation of owners of unencumbered plots of land. The owners of the buildings and, especially, the owners of the flats felt unhappy because, in their understanding, the 'mandatory rental payment' caused an additional burden. They frequently refused to enter into an agreement with the owner of the encumbered plot of land. This led to numerous cases of litigation.

Several research works were commissioned by the Ministry of Justice with the goal of improvement to the legislation. Some results were published even in 2008. Legal opinion focusing on the legal framework of ius in re aliena in the Latvian CL stressed the necessity of introducing new institutions-the long lease (emphyteusis) and the right to erect a building on another's land (superficies). ${ }^{*}{ }^{31}$

Another legal opinion devoted to consequences of the system of divided property in practice suggested that some changes had to be carried out in the regulation of divided property after the achievement of land reform in Latvia. ${ }^{*}{ }^{32}$

Although none of the above-mentioned legal opinions insisted that legal reform in this area was urgent, the Ministry of Justice continued its work, ordering further developments, which were targeted at, if not complete elimination of the situation of divided property, at least a move toward diminishing its negative effects in relation to property matters.

A special team was established within the Ministry of Justice to draft proposals for eradication of the system of dual, or, as it was called at the time, divided property. The misleading term 'divided property' apparently came into being because some members of the above-mentioned working group saw an analogy between the situation they were facing and that present when the original Latvian CL came into force, back in 1937.

29 Latvijas Republikas Satversmes tiesas 15.4.2009. spriedums 'Par likuma 'Par zemes reformu Latvijas Republikas pilsētās' 12.panta otrās daḷas vārdu 'daudzdzīvokḷu dzīvojamās mājas' un pārejas noteikumu 7.punkta un likuma 'Par valsts un pašvaldību dzīvojamo māju privatizāciju’ 54.panta otrās daḷas pirmā teikuma un pārejas noteikumu 40.punkta atbilstību Latvijas Republikas Satversmes 1. un 105.pantam' (judgement by the Constitutional Court of the Republic of Latvia adopted on 15.4.2009 on compliance of the wording 'multi-apartment residential houses' under the second part of Section 12 of the law 'On the Land Reform in the Cities of the Republic of Latvia' and of Section 7 of the transitional provisions and of the first sentence of the second part of Section 54 of the law 'On Privatisation of the State and Municipal Buildings' and of Section 40 of the transitional provisions with Sections 1 and 105 of the Constitution of the Republic of Latvia). 'Latvijas Vēstnesis', 60 (4046), 21.4.2009 (in Latvian).

30 Latvijas Republikas Satversmes tiesas 27.1.2011. spriedums 'Par likuma 'Par zemes reformu Latvijas Republikas pilsētās' pārejas noteikumu 7. punkta, ciktāl tas attiecas uz zemi zem daudzdzīvokḷu mājām, un likuma 'Par valsts un pašvaldību dzīvojamo māju privatizāciju' pārejas noteikumu 40.punkta atbilstību Latvijas Republikas Satversmes 1. un 105.pantam' (judgement by the Constitutional Court of the Republic of Latvia adopted on 27.1.2011 on compliance of Section 7 of the transitional provisions of the law 'On the Land Reform in the Cities of the Republic of Latvia' as far as it pertains to the land underneath multi-apartment buildings and of Section 40 of the transitional provisions of the law 'On Privatisation of the State and Municipal Buildings' with Sections 1 and 105 of the Constitution of the Republic of Latvia). 'Latvijas Vēstnesis', 17 (4415), 1.2.2011 (in Latvian).

31 J. Rozenfelds. Pētījums par Civillikuma Lietu tiesību dalas (ceturtās, piektās, sestās un septītās nodaḷas) modernizācijas nepieciešamību ['Research on the necessity of updating the chapters on property law (IV, V, VI, and VII). Available at www. tm.gov.lv/files/archieve/lv_documents_petijumi_cl_ceturta_piekta_sesta_un_septita_nodala.doc(most recently accessed on 4.2.2014) (in Latvian).

32 PAR: nekustamā īpašuma tiesību regulējums pēc zemes reformas pabeigšanas - Civillikuma zemes un ēku nedalāmības koncepta pilnīgas ieviešanas problēma ['On regulation of ownership rights after accomplishment of the land reform-the problem of complete implementation of the principle of integrity of the land and building in the Civil Law']. Available via http://www.tm.gov.lv/lv/nozares-politika/petijumi (most recently accessed on 4.2.2014) (in Latvian). 
Such an analogy seems to be completely unfounded and the idea doomed to failure. Regulation prescribed in the legislation that preceded the CL of 1937 envisaged the existence of a surface (dominium directum, or Ober-Eigentum) and of the right to buildings (dominium utile or Unter-Eigentum). Unlike in the present situation, the two were recorded in the same division of the Land Register. ${ }^{*} 33$ The law designed back in 1938 that would have empowered owners of the rights to buildings (again, dominium utile or UnterEigentum) to buy out the rights to the land within five years ${ }^{*} 34$ was never fully implemented-both sets of property rights in the 'competition' came to an abrupt end on account of the nationalisation carried out under the Soviet system in the 1940s.

Nevertheless, that law was taken as a model for several draft laws that should lead to the same result by means of no fewer than 20 steps in an extremely complicated procedure through which owners of dwellings eventually must become full owners of the undivided property, leaving the previous land-owners with monetary compensation.

It is no wonder that the concept has still not been fully implemented in the five years since. The concept was released in 2013. ${ }^{*} 35$

Several acts had to be amended for the reaching of the latter target. ${ }^{*}{ }^{*}$

Once the principle of superficies solo cedit is disrupted, it is enormously difficult, if not impossible, to set matters right. Any rights to land once registered become absolute, with the consequence that this step is in many cases irreversible. Although skill and great efforts are invested, there seem to be few opportunities to obtain effective results in the foreseeable future. Whatever the outcome might be, it is doubtful whether the consequences of ill-fated 'exceptions' to the principle of superficies solo cedit as prescribed by Section 968 of the CL and established by the law On [the] Time and Procedures for Coming into Force of [the] Introduction, Inheritance and Property Law Part of the Renewed Civil Law of the Republic of Latvia of 1937 of 7 July 1992 will ever be completely reversed, with a return to normality. Once established, any rights to land inevitably become permanent, and once registered in the Land Register, they become public and virtually irreversible. Any attempt even to scratch them against the will of the person whose rights might be diminished through rectification of registration, would be regarded as an act of deprivation.

\section{Conclusions}

Four points can be made in summary. Firstly, there is significant difference between the present legal regulation and the pre-war regulation. Secondly, Latvian experience shows that once the principle of superficies solo cedit is disrupted, it is extremely difficult, if not impossible, to put things right. A third key point is that any rights to the land once registered are rendered absolute, and this in many cases also means their becoming irreversible.

Finally, land registration in Latvia is too complicated, and it features unnecessary deviations from the main principles recognised for land registration. This is a situation that needs to be corrected.

33 V. Bukovsky. Codification of Local Laws of the Baltic regions with amendments of 1912-1914 and with comments in two volumes. Vol. I. Riga: Typography of G.Gempel and Co, 1914, p.406 (in Russian). F. Konradi, A. Valters. Lietu tiesības. Baltijas vietējo likumu kopojuma trešās daļas skaidrojumi ['Property Law: Explanations to Part III of the Codification of the Baltic Local Laws']. Riga, Latvia 1935, p. 211 (in Latvian).

34 Ministru Kabineta 1938. g. 8 dec. Likums par dalītu īpašuma tiesību atcelšanu (law adopted by the Cabinet on 8 December 1938, 'On Cancellation of Divided Ownership Rights'). Riga, Latvia: Likumu un Ministru kabineta noteikumu krājums 1938, p. 46 (in Latvian).

35 Tieslietu ministrijas redzējums par dalītā īpašuma problemātikas risinājumu konceptu (Vision of the Ministry of Justice on Solution of the Problem of Split Ownership Rights), 22.6.2013 Available at http://www.tm.gov.lv/lv/cits/tieslietu-ministrijas-redzejums-par-dalita-ipasuma-problematikas-risinajumu-konceptu- (most recently accessed on 4.2.2014) (in Latvian).

36 Likums 'Par valsts un pašvaldību dzīvojamo māju privatizāciju' (Law on Privatisation of the State and Municipal Buildings). 'Latvijas Vēstnesis', 103 (386), 11.7.1995 (in Latvian); Likums 'Par zemes reformu Latvijas Republikas pilsētās' (Latvian Cities Land Reform Act); Likums 'Par atjaunotā Latvijas Republikas 1937.gada Civillikuma ievada, mantojuma tiesību un lietu tiesību daḷas spēkā stāšanās laiku un kārtību’ (law ‘On [the] Time and Procedures for Coming into Force of [the] Introduction, Inheritance and Property Law Part of the Renewed Civil Law of the Republic of Latvia of 1937'); Civil Law. 